九州大学学術情報リポジトリ

Kyushu University Institutional Repository

\title{
The Effects of the PACT Microfinance Program in the Dry Zone Area of Central Myanmar
}

Lhing, Nem Nei

Laboratory of Farm Management, Division of International Agricultural Resource Economics and Business Administration, Department of Agricultural and Resource Economics, Graduate School of Bioresource and Bioenvironmental Sciences, Kyushu

Shinkai, Shoji

Faculty of Agriculture, Kyushu University

Hotta, Kazuhiko

Faculty of Agriculture, Kyushu University

Nanseki, Teruaki

Faculty of Agriculture, Kyushu University

https://doi.org/10.5109/17820

出版情報：九州大学大学院農学研究院紀要. 55 (1)，pp. 173-180，2010-02-26. Faculty of Agriculture, Kyushu University

バージョン：

権利関係 : 


\title{
The Effects of the PACT Microfinance Program in the Dry Zone Area of Central Myanmar
}

\author{
Nem Nei LHING ${ }^{1}$, Shoji SHINKAI ${ }^{2}$, Kazuhiko HOTTA ${ }^{2}$ \\ and Teruaki NANSEKI ${ }^{2}$
}

\begin{abstract}
Laboratory of Farm Management, Division of International Agricultural and Resource Economics and Business Administration, Department of Agricultural and Resource Economics, Graduate School of Bioresource and

Bioenvironmental Science, Kyushu University, Fukuoka 812-8581, Japan

(Received October 30, 2009 and accepted November 19, 2009)
\end{abstract}

\begin{abstract}
Microfinance (MF) has developed as a vital move towards the promotion of community development and poverty alleviation goals through the provision of small loans to low income individuals, households and enterprises. MF for poor people has become an increasingly against poverty in developing countries worldwide. Reducing the proportion of people living on less than a dollar per day by half by 2015 is a part of the Millennium Development Goals. This study examined the effects of the Private Agency Collaborating Together (PACT) microfinance program in Dry Zone Area of Central Myanmar. The Research has been carried out in six villages of Dry-Zone Area in central Myanmar. The analysis uses 2008 cross-sectional survey data on 162 randomly selected households. Descriptive analysis shows that the respondents who participated (clients) are improving of their living standard and more total income than those who did not participate (non-clients) in the program. The result from logistic regression model suggests that marital status of respondents, gender of household head, education level, number of crops, changes farming practices and established new business are strongly associated with taking loan and the presence of these variables increases the probability of being taken loan. Household size, age of respondents and land holding size are also highly significant variables but having negative impact on the probability of taking loan. Therefore, MF program helps client households to reduce their financial vulnerability through diversification of income sources.
\end{abstract}

\section{INTRODUCTION}

About three billion people, half of the world's population, are living on the income of less than two dollars a day. Poverty remains a matter of growing concern in many developing countries of the world. One study in 2006 showed that the ratio of the income between the $5 \%$ richest and $5 \%$ poorest of the population was 74 to 1 as compared to the ratio in 1960 , which was 30 to 1 . To enhance international development, the United Nations Organization (UNO) had introduced eight millennium development goals which aimed to eradicate poverty by half by 2015 .

In Myanmar, World Bank study from 1999 indicated that the poverty incidence was, on average, $22.9 \%$ of the overall population and $69.6 \%$ of the total population are living in rural areas. Time series data from household income and expenditure studies confirm that overall poverty has not declined in recent years. In terms of food security, Myanmar has accomplished surplus food production at national level, but there are food deficit areas, mostly located in the central dry zones, Shan and Chin States.

According to the report of FAO and Vulnerability Information and Mapping System (FIVIMS) program (UNDP-Myanmar, 2003) indicated that out of the national

\footnotetext{
${ }^{1}$ Laboratory of Farm Management, Division of International Agricultural Resource Economics and Business Administration, Department of Agricultural and Resource Economics, Graduate School of Bioresource and Bioenvironmental Sciences, Kyushu University

${ }^{2}$ Faculty of Agriculture, Kyushu University

* Corresponding author ( E-mail: nanseki@agr.kyushu-u.ac.jp)
}

total of 324 townships, 52 townships were classified as being very highly vulnerable, 49 highly vulnerable, 62 moderately vulnerable, and the remaining 122 having a relatively low level of vulnerability. Among the 52 very highly vulnerable townships, 29 were located in Shan State. All townships in Chin State and two-third of townships in Kachin State were also reported to be highly vulnerable and mostly located in remote areas. Townships in Bago Division, Mon State, and Yangon Division were reported to be the least vulnerable.

In this regard, microfinance is the form of financial development that has its primary aim to alleviate the poverty and also which is significant source of finance for poor, lower income people in Myanmar. Government, donors and NGOs around the world responded enthusiastically with plans and promised to work together towards the realization of these goals.

Therefore the objectives of this research are: to compare the demographic and socio-economic characteristics of the clients and non-clients, to investigate the impact of PACT MF program on changes in earned income, household assets, crop diversification, technology, education, saving, food intake, clothing, housing improvement and health aspects of the clients and finally to examine the determinants or influencing factors on taking loans. The analysis used data on 102 clients who are participating in the program and 60 who are not participating. To do a case study, PACT Myanmar MF program which is operating in Dry Zone Area of central Myanmar was chosen 


\section{STUDY AREA AND METHODOLOGY}

Kyaukpadaung Township is considered as a case study for Dry Zone Area of central Myanmar. There are 339 villages composing 109 village tracts and 78,935 households. The total population is about four millions. In study area, 268,703 acres ( 1 ha=2.4 acres) of the total land area are under cultivated land. Among them, 27,461 acres, 240,736 acres, and 506 acres are for lowland, upland and others respectively. The annual average rainfall is 28.07 inches. The daily average maximum temperature is 41 degree Celsius and average minimum 12 degree Celcius, so high temperature fluctuation. There is an irrigation source, namely Kyetmaut and Pin Dams, mainly for summer rice cultivation. The major economic activities in this study are agriculture and trade. Agriculture is by far the most important sector with individual small holders as the most important production units.

In October 2008, a survey was conducted of 162 households in six villages which have saving groups by PACT MF program. Two strata are identified taking loans (Clients) and not taking loans (Non-Clients) prior to collecting data. Data collection was done based on the participatory approach and the use of structured questionnaires by random sampling technique. One hundred and two observations are collected for clients stratum and sixty observations for non-clients stratum. The household questionnaire contained data on household demographic and socioeconomic characteristics such as age, household size, gender, their assets, income, expenditure, health aspect, adoption of advanced technology, number of crops, participating in social activities, established new business etc. The data for village information was collected through the president of the village and members of the village committee.

Descriptive analysis is largely used to determine the comparison between two groups of socio-economic char- acteristics and after participating in the program what changes were occurred on clients. Logistic regression analysis is tested to examine the determinants or influencing factors on taking loans.

\section{RESULT AND DISCUSSION}

The socio-economic characteristic of the clients and non-clients are as shown in Table 1. These characteristics provide descriptive overview of households with regards to household size, marital status, gender, age, and educational level of respondents.

In terms of gender distribution of the respondents, $77.5 \%$ of the clients are female while $22.6 \%$ are male. The main shares of the respondents are women that testify to the fact that most of the beneficiaries of MF are female. There are good reasons to target women by MF because gender discrimination is one of the major causes of poverty, slower economic growth, weaker governance, lower standards of living and women are poorer and more disadvantaged than men. In some MF institutions like the Grameen Bank which is the biggest microfinance institution in terms of outreach, $96 \%$ of their clients are women.

In terms of age, although $50.0 \%$ of the clients are in the age group of 36 to 50 years, non-clients are $21.7 \%$. It can be concluded that the younger the age of the respondents the more they want to participate in the program. From this survey, many of the clients had at least middle education which represents $42.4 \%$ of the clients, however for non-clients about 22\%.

According to my result of marital status, $1.7 \%$ of non-clients still single when in clients $35.3 \%$ which indicates that respondents who unmarried are more likely to join in microfinance program. In my study, the average family size of the clients ( $5.5 \mathrm{ppl})$ is lower than non-clients (7.2 ppl). It is because as mentioned before $35.3 \%$ of clients still unmarried.

Table 1. Demographic and socioeconomic characteristics of the respondents by categories

\begin{tabular}{|c|c|c|c|c|c|}
\hline \multirow{2}{*}{ Variables } & \multirow{2}{*}{$\begin{array}{l}\text { Measuring } \\
\text { Group }\end{array}$} & \multicolumn{2}{|c|}{ Clients (102) } & \multicolumn{2}{|c|}{ Non-Clients (60) } \\
\hline & & Frequency & Percentage & Frequency & Percentage \\
\hline \multirow{2}{*}{ Gender } & Male & 23 & 22.5 & 43 & 71.7 \\
\hline & Female & 79 & 77.5 & 17 & 28.3 \\
\hline \multirow{3}{*}{ Age(years) } & $<35$ & 23 & 22.5 & 6 & 10.0 \\
\hline & $36-50$ & 51 & 50.0 & 13 & 21.7 \\
\hline & $>51$ & 28 & 27.5 & 41 & 68.3 \\
\hline \multirow{2}{*}{$\begin{array}{l}\text { Marital } \\
\text { Status }\end{array}$} & Married & 66 & 64.7 & 59 & 98.3 \\
\hline & Single & 36 & 35.3 & 1 & 1.7 \\
\hline \multirow{4}{*}{ Educational } & Not at all & 18 & 17.6 & 13 & 21.7 \\
\hline & Primary & 29 & 28.2 & 31 & 51.7 \\
\hline & Middle & 43 & 42.4 & 13 & 21.7 \\
\hline & High & 12 & 11.8 & 3 & 4.9 \\
\hline \multirow{2}{*}{ Family size } & $<5$ & 58 & 57.0 & 18 & 30.0 \\
\hline & $>5$ & 44 & 43.0 & 42 & 70.0 \\
\hline
\end{tabular}

Source: field survey, 2008 
Comparative Analysis between Client and NonClient households

General household income

With regard to the general changes in total household income over the previous 12 months, there are a proportionately larger number of clients who noticed an increase. In fact, about $53.0 \%$ of them felt that their household incomes have increased while only $26.6 \%$ of the non-clients could say the same (Table 2). In the same way, in the case of the women who reported a reduction in the family income, it may be observed that non-clients experienced this phenomenon more strongly (over $1 / 4^{\text {th }}$ ). Hence, the program's clients seem to be more involved in managing their family budget, possibly due to their increasing and more substantial financial contribution.

Recent situation of saving

Table 3 is to compare the changes in saving of clients versus non-clients. In here we can conclude that about 39\% of the clients have an increase in saving com- pared to about $23 \%$ of the non-clients. Non-clients listed a problem with their business and weather failure as the major reasons for a decrease in income and savings. Clients, on the other hand, listed started new business and money received from agricultural products as the major reasons for their increase in income and saving.

Ownership of Durable Assets

An increase in the number of durable assets purchased for the household was regarded as a potentially strong indicator of the impact of microfinance program on their clients. The findings revealed that in every asset category studied, client households are more likely to have acquired the items than non-client households. The differences between the comparison groups on each item are highly significant (Table 4). The exception in Radio, Pig and Chicken items were not significantly proportion of client than non-client households.

Crop Diversification

Crop diversification was generally regarded as a positive change. It indicates households were diversifying

Table 2. The household's overall income over the last 12 months

\begin{tabular}{lcccccc}
\hline \multirow{2}{*}{ Measuring group } & \multicolumn{2}{c}{ Clients (102) } & & \multicolumn{2}{c}{ Non-Clients (60) } \\
\cline { 2 - 3 } \cline { 5 - 6 } & Frequency & Percentage & & Frequency & Percentage \\
\hline Decreased & 14 & 13.7 & & 16 & 26.6 \\
Stay the same & 34 & 33.4 & & 28 & 46.8 \\
Increased & 54 & 52.9 & & 16 & 26.6 \\
\hline Total & 102 & 100 & & 60 & 100 \\
\hline
\end{tabular}

Source: field survey, 2008

Table 3. The situation of households saving

\begin{tabular}{lcccccc}
\hline \multirow{2}{*}{ Measuring group } & \multicolumn{2}{c}{ Clients (102) } & & \multicolumn{2}{c}{ Non-Clients (60) } \\
\cline { 2 - 3 } \cline { 5 - 6 } & Frequency & Percentage & & Frequency & Percentage \\
\hline \multirow{2}{*}{ Decreased } & 24 & 23.5 & & 31 & 51.7 \\
Stay the same & 38 & 37.3 & & 15 & 25.0 \\
Increased & 40 & 39.2 & & 14 & 23.3 \\
\hline Total & 102 & 100 & & 60 & 100 \\
\hline
\end{tabular}

Source: field survey (2008)

Table 4. Percentage of households acquiring major durable assets

\begin{tabular}{llccc}
\hline Items & Measuring group & Units & Clients (102) & Non-Clients (60) \\
\hline \multirow{5}{*}{ Household assets } & TV & $\%$ & 55.9 & 42.0 \\
& VCD & $\%$ & 38.2 & 20.0 \\
& Sewing machine & $\%$ & 56.9 & 26.7 \\
& Cassette & $\%$ & 67.6 & 41.7 \\
& Radio & $\%$ & 62.7 & 85.0 \\
& Motor cycle & $\%$ & 38.2 & 20.0 \\
& Bicycle & $\%$ & 83.3 & 56.7 \\
& Fan & $\%$ & 39.2 & 21.7 \\
\hline \multirow{5}{*}{ Livestock assets } & $\%$ & 83.3 & 70.2 \\
& Cow & $\%$ & 30.4 & 46.7 \\
& Pig & $\%$ & 42.2 & 55.0 \\
& Goat & $\%$ & 31.4 & 26.7 \\
& Sheep & $\%$ & 39.4 & 23.3 \\
& Horse & $\%$ & 16.7 & 10.0 \\
\hline
\end{tabular}

Source: field survey (2008) 
production in response to market opportunities, while it also suggested that the respondent may be diversifying to reduce risk of failure of a particular crop. In the study area, on average, clients grew 4.5 crops and non-clients 3.2 crops (Table 5). A comparison between the numbers of crop cited shows that clients are significantly more likely than non-clients. Clients' increased expenditure on agricultural inputs, expansion of land, and increase in the number of crops grown are all positively related to program participation.

Table 5. The number of crops grown by both respondents

\begin{tabular}{llcc}
\hline Items & Units & Clients(102) & Non-Clients(60) \\
\hline Average & Number & 4.5 & 3.2 \\
Maximum & Number & 7.0 & 5.0 \\
Minimum & Number & 2.0 & 1.0 \\
\hline
\end{tabular}

Source: field survey (2008)

The Impact of Microfinance on Client Households' Livelihoods

Use of Loan Funds

The PACT microfinance program emphasizes the use of loan funds in the respective enterprise. Clients may use part or all of the loan funds in their agriculture fields, small micro-enterprises. The loan funds tend to be used on agriculture and enterprise. Some funds are also used for household needs, and the use of the funds varied across a range of needs such as school expenditures, food, and loan repayments (Table 6).

Table 6. Distribution of items on which Clients mostly spent their loans

\begin{tabular}{lcc}
\hline Microfinance loan expenditure & Units & Clients (N=102) \\
\hline Investment in agriculture & $\%$ & 85 \\
Small micro-enterprise & $\%$ & 53 \\
School expenditures & $\%$ & 42 \\
Food for household & $\%$ & 27 \\
Medical care & $\%$ & 15 \\
Savings & $\%$ & 15 \\
Debts & $\%$ & 11 \\
Others & $\%$ & 6 \\
\hline
\end{tabular}

Note: Multiple responses possible

Source: field survey (2008)

\section{Household's Saving}

One of the components of the program is a requirement to save on a regular basis. The clients were asked if they had personal savings excluding the forced loan guarantee. The above figure. 1 reflects that the majority of the clients (82\%) responded to have personal savings while $18 \%$ said they had no saving.

Again with regard to saving, the clients were asked whether their saving in the last 12 months had increased, decreased, or remained the same. The response was demonstrated that about $39.2 \%$ having increased saving while $23.5 \%$ said decreased and $37.3 \%$ said remained constant (Fig. 2). Saving can provide protection against risks and also to expand the existing economic activities. However some clients prefer to save in physical assets such as land, TV, motor cycle, gold, houses and other valuables after the obligatory loan guarantee savings.

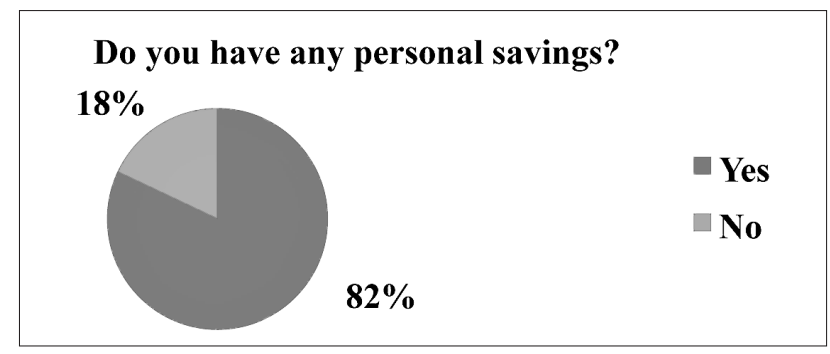

Source: field survey (2008)

Fig. 1. Personal saving.

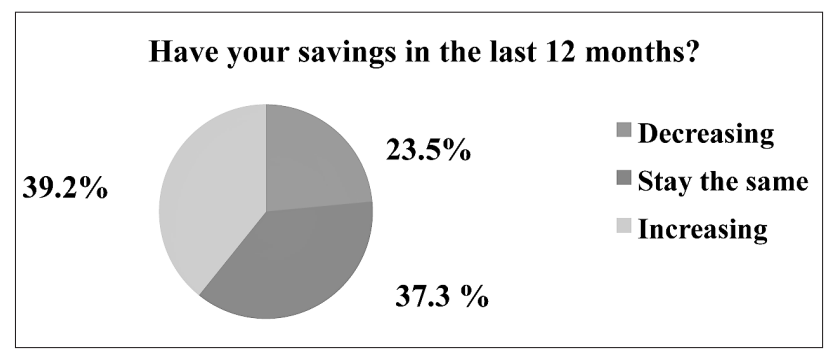

Source: field survey (2008)

Fig. 2. The situation of saving in the last 12 months.

\section{Overall Households' Income}

The generation of income is another ingredient and the majority of the client's responded positively that they have registered 53\% increment in incomes as shown in figure. 3 while 14\% noted a decrease and 33.4\% remained the same. Clients who increased income reported that agriculture and small micro-enterprise profits are an important income source for them. Especially in those who run businesses like small micro-enterprise have higher income than agriculture.

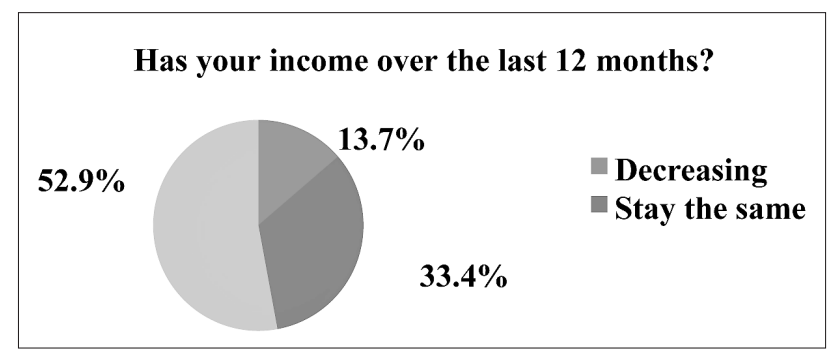

Source: field survey (2008)

Fig. 3. The situation of household income over the last 12 months.

\section{Condition of Children's Schooling}

Concerning about how many children are going to school before and after participating loans, the responses were very positively because of their facilitation by PACT microfinance program. Many of the clients have almost enrolled all their children to school. Before taking loan, only 125 students could attend to school however after 
taking loan 169 (89\%) students can now attending school. Many clients praised PACT microfinance program which has given them a push to cater for their children Table 7 .

Table 7. The comparison of children schooling before and after participating program

\begin{tabular}{lc}
\hline Items & Clients (N=102) \\
\hline Schooling aged in household & 206 \\
Before participating in microfinance program & 125 \\
After participating in microfinance program & 169 \\
\% of schooling at present & 89
\end{tabular}

Source: field survey (2008)

\section{Health}

Health is an important ingredient for protecting the productivity of the household's effective use of the household resources. It is evident that most clients interviewed took household health as a critical issue for their continued well being. At least more than half of the households had a sick person in the household in the last two weeks of the interview and the most prevalent illness in the household was vomiting and diarrhea. This could have been because of the rainy season. All the clients could afford to visit health clinics and hospitals and also could afford to pay the medical expenses every time a member of the household could fall sick.

Technology Adoption

In the study area, out of 102 clients, 59 of them (57.8\%) adopted one or more innovations from Agricultural Extension and NGOs. Table 8 shows that

Table 8. The number of clients in adoption of technology

\begin{tabular}{lcc}
\hline \multirow{2}{*}{ Items } & \multicolumn{2}{c}{ Clients (N=59) } \\
\cline { 2 - 3 } & Frequency & Percentage (\%) \\
\hline \multirow{2}{*}{ Planted improved seeds } & 27 & 45.8 \\
Used chemical fertilizer & 12 & 20.3 \\
Changed cropping pattern & 10 & 16.9 \\
Processed farm produce & 7 & 11.8 \\
Others & 3 & 5.2 \\
\hline Total & 59 & 100 \\
\hline \multirow{2}{*}{ Source: field survey (2008) } & &
\end{tabular}

the innovations most adopted by clients were planting improved seeds, use of chemical fertilizer, processing of farm produce and changed cropping pattern.

\section{Food Intake}

For the large majority of the entire sample, more than a half (62.8\%) of clients felt that there has been an improvement in their food intake (Table 9). However, among the clients, it may be noted that (28\%) of the households' food intake remained the same over the previous 12 months. On the other hand, a less number of clients $(9 \%)$ felt that the situation have worsened in this regard

Housing Improvement

As far as the impact of the program on improvements in living conditions is concerned, $84.6 \%$ of the clients asserted that they have undertaken repairs or improvements in the roof, floors, etc. (Table 10). Amongst the clients, a large majority $84.6 \%$ specified that these works have been undertaken only after they joined the program. In the case of housing expansion, $37.2 \%$ of the clients have done such work. Concerning to the improved water and sanitation system, the percentage was only $24 \%$, however, the large majority of clients (94\%) also specified that they undertook this work only after they had joined the program. However, what is certain is that clients carried out improvements once they joined the program

The Influencing Factors on Taking Loan by using Logistic Regression Model

Logistic Regression Model is a form of regression which is used when the dependent variable is dichotomy and the independents are of any types (categorical and continuous variables). The formula for the logistic regres-

Table 9. The impact of microfinance program on food intakey

\begin{tabular}{lcc}
\hline \multirow{2}{*}{$\begin{array}{l}\text { During the last 12 months has } \\
\text { your food intake: }\end{array}$} & \multicolumn{2}{c}{ Clients (N=102) } \\
\cline { 2 - 3 } & Frequency & Percentage (\%) \\
\hline Worsened & 9 & 8.8 \\
Stay the same & 29 & 28.4 \\
Improved & 64 & 62.8 \\
\hline Total & 102 & 100 \\
\hline
\end{tabular}

Source: field survey (2008)

Table 10. The impact of microfinance program on living conditions

\begin{tabular}{lccc}
\hline \multicolumn{1}{c}{$\begin{array}{c}\text { During the last 2 years, were any repairs, } \\
\text { improvements or additions made to your home? }\end{array}$} & Units & $\begin{array}{c}\text { Clients } \\
\text { (N=102) }\end{array}$ & $\begin{array}{c}\text { \% of members } \\
\text { of the program }\end{array}$ \\
\hline $\begin{array}{l}\text { House repairs or improvements (fixed or improved } \\
\text { existing roof, floor, walls or kitchen) }\end{array}$ & $\%$ & 84.6 & 84.8 \\
$\begin{array}{l}\text { House expansion (built new rooms, shed, fence or } \\
\text { wall) }\end{array}$ & $\%$ & 37.2 & 86.2 \\
$\begin{array}{l}\text { Improved water or sanitation system (new well, } \\
\text { latrine) } \\
\text { Lighting or electricity } \\
\text { Others }\end{array}$ & $\%$ & 24.0 & 94.4 \\
\hline
\end{tabular}

Note: Multiple responses possible

Source: field survey (2008) 
sion in this analysis is as follows:

$$
\begin{aligned}
\mathrm{Yi} & =\beta_{0}+\beta_{1} \mathrm{X}_{1 \mathrm{i}}+\beta_{2} \mathrm{X}_{2 \mathrm{i}}+\beta_{3} \mathrm{X}_{3 \mathrm{i}}+\beta_{4} \mathrm{X}_{4 \mathrm{i}}+\beta_{5} \mathrm{X}_{5 \mathrm{i}}+\beta_{6} \mathrm{X}_{6 \mathrm{i}} \\
& +\beta_{7} \mathrm{X}_{7 \mathrm{i}}+\beta_{8} \mathrm{X}_{8 \mathrm{i}}+\beta_{9} \mathrm{X}_{9 \mathrm{i}}+\beta_{10} \mathrm{X}_{10 \mathrm{i}}+\beta_{11} \mathrm{X}_{11 \mathrm{i}}+\mathrm{e}_{\mathrm{i}}
\end{aligned}
$$

Where: $\mathrm{Y} \quad=$ Dependent variable (if respondent is taking loan: $\mathrm{y}=1$ and if no: $\mathrm{y}=0$ )

$\mathrm{X}_{1}-\mathrm{X}_{11}=$ Independent variables

$\mathrm{e}_{\mathrm{i}} \quad=$ Error terms

$\beta_{1}-\beta_{11}=$ Estimated coefficients

The list of some selected variables for this model is given in Table 11 which gives a description of the varia- bles, hypothesis and the expected signs for each of the estimated coefficients. This table is followed by a description of extant literature of the 11 factors- family size, marital status, gender, age, education, land holding size, number of crops, income, technology adoption, participating in social activity, and establishing new business- that determine taking loan.

The results of the estimation of the logistic regression model are presented in Table 12. Analysis of the survey data revealed that nine out of the eleven variables included in the model (Table 12) are significant (at 1 percent to 10 percent) in explaining the variation in tak-

\begin{tabular}{|c|c|c|}
\hline Variables & Description of variables & Hypothesis \\
\hline Dependent var: & $=1$ if household is taking loan & \\
\hline Taking loan & $=0$ if household is not taking loan & \\
\hline \multicolumn{3}{|l|}{ Independent var: } \\
\hline FSize & Size of the Household & $\begin{array}{l}\text { Increasing family size of the Respondents are } \\
\text { more likely to taking loan }(+)\end{array}$ \\
\hline MStatus & $\begin{array}{l}\text { Marital Status } \\
(1=\text { Single, } 0=\text { Married })\end{array}$ & $\begin{array}{l}\text { Single respondents more willingly to join on } \\
\text { taking loan }(+)\end{array}$ \\
\hline Gender & Gender $(1=$ Female, $0=$ male $)$ & $\begin{array}{l}\text { Female respondents are more likely to participate } \\
\text { in taking loan }(+)\end{array}$ \\
\hline Age & Age (Years) & $\begin{array}{l}\text { Older head of households are less likely to } \\
\text { participate in taking loan }(-)\end{array}$ \\
\hline Edu:Level & Educational Level (Years) & $\begin{array}{l}\text { Higher level of head of households are more likely } \\
\text { to participate in taking loan }(+)\end{array}$ \\
\hline LHSize & Land Holding Size (Acres) & $\begin{array}{l}\text { Higher land holding size of respondents are more } \\
\text { likely to join taking loan }(+)\end{array}$ \\
\hline NCrops & Number of Crops & $\begin{array}{l}\text { Respondents with increasing number of crops are } \\
\text { more likely to join in taking loan }(+)\end{array}$ \\
\hline Income & Income per year (Kyats) & $\begin{array}{l}\text { Higher income per year of respondents are less } \\
\text { likely to join in taking loan }(+) \text { or }(-)\end{array}$ \\
\hline Tech:Adop & $\begin{array}{l}\text { Technology adoption } \\
(1=\text { Yes, } 0=\text { No })\end{array}$ & $\begin{array}{l}\text { Higher changing farming practices may increase } \\
\text { access and participate in taking loan }(+)\end{array}$ \\
\hline Soc:Act & $\begin{array}{l}\text { Participating in social activity } \\
(1=\text { Yes, } 0=\text { No })\end{array}$ & $\begin{array}{l}\text { Respondents who are more participating in village } \\
\text { activities more likely to join in taking loan }(+) \\
\text { Household who established new business have }\end{array}$ \\
\hline Est:Buss & Established new business $(1=\mathrm{Yes}, 0=\mathrm{No})$ & high opportunity to participate in taking loan $(+)$ \\
\hline
\end{tabular}

Table 11. List of variables affecting taking loan for Logistic Regression Analysis

\begin{tabular}{|c|c|c|c|c|c|}
\hline $\begin{array}{c}\text { Independent } \\
\text { Variables }\end{array}$ & $\begin{array}{c}\text { Coefficients } \\
\beta\end{array}$ & $\begin{array}{c}\text { Std. Error } \\
\text { S.E }\end{array}$ & $\begin{array}{c}\text { Wald } \\
\text { Statistics }\end{array}$ & Significance & $\begin{array}{l}\operatorname{Exp}(\beta) \text { or } \\
\text { Odds ratio }\end{array}$ \\
\hline FSize & -0.77 & 0.23 & 11.17 & $* * *$ & 0.46 \\
\hline MStatus & 2.83 & 1.22 & 5.42 & $* *$ & 16.92 \\
\hline Gender & 2.10 & 0.89 & 5.61 & $* *$ & 8.18 \\
\hline Age & -0.15 & 0.05 & 7.75 & $* * *$ & 0.86 \\
\hline Edu:level & 0.45 & 0.18 & 6.40 & $* *$ & 1.57 \\
\hline LHSize & -0.34 & 0.14 & 6.32 & $* *$ & 0.71 \\
\hline NCrops & 1.36 & 0.54 & 6.28 & $* *$ & 3.90 \\
\hline Income & 0.00 & 0.00 & 0.13 & n.s & 1.00 \\
\hline TechAdop & 1.82 & 0.97 & 3.53 & $*$ & 6.16 \\
\hline SocAct & 0.76 & 0.85 & 0.80 & n.s & 2.14 \\
\hline Estbus: & 2.56 & 0.95 & 7.21 & $* *$ & 12.93 \\
\hline Constant & 3.21 & 2.31 & 1.12 & n.s & 11.54 \\
\hline
\end{tabular}

Table 12. The Results of Logistic Regression Analysis

Number of Sample Size $=162$

Nagelkerke R square $=0.85$, Correctly predicted $=93.2 \%$

$* * *, * *, *$ indicate significance level at $1 \%, 5 \%$ and $10 \%$, respectively

Source: own estimate 
ing loans status of household in the study area. These variables are family size, marital status, gender, age, educational level, land holding size, number of crops, technology adoption, and establishing new business and have signs in accordance with my hypotheses except family size and land holding size. The coefficients of Income and participating in social activities are insignificant variables.

The age of the respondents has a negative coefficient with significant at $1 \%$ level. This probably indicates that the older the respondents, the lower the probability that household would be taking loan. The younger respondents tend to be directly participated by increasing rate of taking loan than older respondents. In terms of the household size, it is highly significant at $1 \%$ level and having negative impact on the probability of taking loan. It suggests that higher household size has a decreasing rate on taking loan. It is because in my survey most of the clients have few members in their family, which indicates that respondents are either unmarried, or have no children. On the other hand, 98\% of non-clients are married and almost their family members interested in working farms, which indicates that they don't want to participate in the microfinance program.

The results also shows that the income variable is insignificant which means that there is no relationship and not affecting between whether the income higher or lower and taking loan. Apart from income, the other significant variables in the model are the educational level, gender of the respondents, marital status, number of crops did they grow, awareness of technology adoption, and establishing new business. This implies that the probability of taking loan is higher with educated, female, increased number of crops, higher adopted technology, and established new business. Regarding to the land holding size which is significant at 5\% level, however, affect on taking loan is negatively. For variable of participating in social activity it is insignificant and no matter this variable increase or decrease had no affect on taking loan.

\section{CONCLUSIONS}

The assessment found that program participation had an impact on clients' enterprises, expenditures on household assets, and agricultural activities. Participation in microfinance program has enabled client respondents to receive loans, save, and acquire information from their loan officers and group members about good business practices. In the study area, the majority of the clients used their loans are especially on agriculture and small micro-enterprise. However, at least one-half of the clients used a portion of the loan for non-business purposes to buy food for the family, pay for health care and pay for their children education.

This study is also attempted to analyze influencing factors or determinants of taking loan on PACT microfinance program in Dry Zone Area of Myanmar by using Logistic Regression Model. The main findings of this empirical analysis are: marital status of respondent, gen- der, education level, number of crops, technology adoption and establishing new business are strongly associated with taking loan and the presence of these variables increases the numbers of being taken loan, family size, age of respondent and land holding size are highly significant variables but having negative impact on the program which means that the value of these variables increase the numbers of taking loan decrease.

It can be noticed from overall analysis that there is significant impact of microfinance activity on improvement of the livelihoods of the rural households not only in economic term but also in social term. Regarding to the reasons for not participating, PACT MF is suggested to collaborate with extension services to develop information program in order to disseminate the information to as many people as possible and also the program should be made easier in terms of loan procedures, legal action. More information on the advantage of taking loans should be made in order to attract peoples to join the program. And also the microfinance program should make easier and simple loan procedures, reduce some of their legal action which strategies can make respondents to become easily to join the program.

In order to achieve a greater impact of microfinance program, PACT program should be put appropriate mechanisms to provide the basic social services, especially education and health care, which are needed to improve the quality of life of rural households. The program should introduce more income generating activities and effective education program. These can give more profitable opportunities and can also open up more incomeearning opportunities for the farm households especially in the non-farm sector.

It is recommended that microfinance strategies should be designed in a way that would focus on and address the identified determinants as well as other factors that are related to improving household social wellbeing such as agricultural production, access to market, health education, and subsidy programs.

\section{REFERENCES}

Annoted SPSS Output: Logistic Regression Analysis, UCLA Academic Technology Services, www.ats.ucla.edu/stat/spss/ output/logistic.htm.

Brett E. A. 1993, Providing for the Rural Poor, Fountain Publishers Ltd Kampala-Uganda.

Carla, H., Manohar, S., L.Cecile and M. Zeller, 2003 Microfinance Poverty Assessment Tool, Consultative Group to Assit the Poorest (CGAP).

Fallavier, P. 1998. Developing Micro-Finance institutions in Vietnam, Thesis (M.Sc.), University of British Columbia, Vancouver, Canada.

Fotabong, Leonard A., Kedju, Akanga F. 2005. The Impact of Microfinance Institutions on Poverty Reduction in the South-East Province of Cameroon, Master's Thesis, Umea Business School (USBE), Sweden.

Hatch, J., and L. Frederick. 1998. Poverty Assessment by Microfinance Institutions: A Review of Current Practice. Bethesda, Md.: USAID Microenterprise Best Practices Project/FINCA International/Development Alternatives, Inc..

Hosmer. D. W. and L. Stanley. 2000. Applied Logistic 
Regression, 2nd Ed., Wiley, New York.

Hubka, A., Zaidi, R. 2005. Impact of Government Regulation on Microfinance, World Development Report: Improving the Investment Climate for Growth and Poverty Reduction.

Martin Greely 2003. Poverty reduction \& MicrofinanceAssessing Performance, IDS Bulletin. 34:4 2003

Rahman, M. S. 2003. Direct Aid Delivery-Reaching the Hardcore Poor: UNDP/CBO Case Study in Myanmar, New York, United Nations Development of Economic and Social Affairs. Roy, Mark A. 2003. Microfinance as a Tool for Development, BSUS 6900.

Turnell, S. R. 2005. A Survey of Microfinance Institutions in Burma, Burma Economic Watch, www.mm.undp.org/HDI/ ICDPCDRT.html.

UNDP (United Nations Development Progamme) 2003. Human Development Initiative in Myanmar, Report of Independent
Assessment Mission, New York, UNDP.

UNDP (United Nations Development Programme), 2008/2009.

Statistical Update for Human Development Index, Country Fact Sheets, Myanmar.

UNOPs (United Nations Office for Project Services) 2005 Sustainable Microfinance to Improve the Livelihoods of the Poor Project: Myanmar, MYA/01/004, Bangkok, UNDOPs. Yunus, Muhammad 1999. Banker to the Poor: Microlending and the Battle Against World Poverty, New York: Public Affairs

Zeller, M., Meyer, Richard L. 2002. The Triangle of Microfinance - Financial Sustainability, Outreach, and Impact, Published for the International Food Policy Research Institute, The Johns Hopkins University Press, Baltimore and London. 